Int. J. Electrochem. Sci., 16 (2021) Article ID: 210732

International Journal of

ELECTROCHEMICAL

SCIENCE

www.electrochemsci.org

Mini review

\title{
Electrochemical Biosensors for the Detection of Cancer Biomarkers with Different Signal Amplification Strategies
}

\author{
Ting Sun, Yinli Guo and Feng Zhao*
}

Guizhou Integrated Research Center of Polymer Electromagnetic Materials, School of Chemistry and Materials Science, Guizhou Education University, GaoXin Road 115, Wudang District, Guizhou, 550000, People's Republic of China

*E-mail: fygu2010@163.com

doi: $10.20964 / 2021.07 .62$

Received: 9 April 2021 / Accepted: 11 May 2021 / Published: 31 May 2021

Early diagnosis of cancer is the key to successful treatment. Biomarkers for cancer diagnosis can significantly improve the level of early diagnosis and follow-up treatment. Biosensors play an important role in the detection of biomarkers because they are easy to use, portable and can be used for real-time analysis. In this paper, we introduced the types of electrochemical biosensors and reviewed the signal amplification strategies for electrochemical detection of cancer biomarkers.

Keywords: Electrochemical biosensors; cancer biomarkers; signal amplification; nucleic acid; enzyme; nanomaterials

\section{$\underline{\text { FULL TEXT }}$}

(C) 2021 The Authors. Published by ESG (www.electrochemsci.org). This article is an open access article distributed under the terms and conditions of the Creative Commons Attribution license (http://creativecommons.org/licenses/by/4.0/). 